\title{
The Prevalence and Risk Factors of Sleep Disorders Among Adolescent in Junior High School
}

\section{Defranky Theodorus*, I Gusti Ayu Trisna Windiani, I Gusti Agung Ngurah Sugitha Adnyana, Soetjiningsih}

Department of Child Health, Medical Faculty of Udayana University, Sanglah General Hospital, Denpasar, Bali, Indonesia

\author{
Email address: \\ dokter_franky@yahoo.com (D. Theodorus), trisnawindianidr@yahoo.co.id (I G. A. T. Windiani), \\ sugad168@yahoo.com (I G. A. N. S. Adnyana),prof_soetji@yahoo.com (Soetjiningsih) \\ ${ }^{*}$ Corresponding author
}

\section{To cite this article:}

Defranky Theodorus, I Gusti Ayu Trisna Windiani, I Gusti Agung Ngurah Sugitha Adnyana, Soetjiningsih. The Prevalence and Risk Factors of Sleep Disorders Among Adolescent in Junior High School. American Journal of Pediatrics. Vol. 6, No. 4, 2020, pp. $392-396$.

doi: $10.11648 /$ j.ajp.20200604.12

Received: September 20, 2020; Accepted: September 30, 2020; Published: October 13, 2020

\begin{abstract}
Sleep disorders are collection of symptoms characterized by disruption of amount, quality, or time of sleep. Adolescent are high-risk group for sleep disorders. Sleep disorders among adolescent are affected by various factors such as extracurricular activities, watching television, using computer, using mobile phone and homework could delay sleeping time. This study aimed to find the prevalence and risk factors of sleep disorders among adolescent in Junior High School. It was a cross-sectional study among students in St. Joseph Junior High School, Denpasar aged 12-15 years old in August 2019, by using stratified purposive sampling. Data was collected by using Sleep Disturbance Scale for Children (SDSC) which was filled by parents and children. Chi-square test and logistic regression were used for statistical analysis. This study showed the prevalence of sleep disorders was $47.8 \%$. Disturbance with initiating and maintaining sleep was the most common disorder, 22.8\%. Watching television, using computers and playing telephone / gadgets were associated with increased sleep disturbance $(\mathrm{p}=0.02$, PR 3.17, CI 95\% 1.17-8.59), $(\mathrm{p}=0.02$, PR 2.64 CI 95\% 1.14-6.14), $(\mathrm{p}=0.02, \mathrm{PR} 2.94$, CI 95\% 1.12-7.7), while extracurricular activities, nap habits, caffeine consumption were not risk factors, ( $p=0.07$, PR 2.3, CI95\% 0.94-5.95), ( $p=0.28$, PR 1.57 CI 95\% 0.68-3.58), ( $\mathrm{p}=0,78$, PR 0.89, CI 95\% 0.38-2.03). The prevalence of sleep disorder among adolescent was considerably high. Risk factors of sleep disorder were watching television, using computer, and using mobile phone/gadget.
\end{abstract}

Keywords: Sleep Disorder, Adolescent, Sleep Disturbance Scale for Children

\section{Introduction}

Sleep is very important for children and adolescents, which affect learning, memory processes and school performance [1]. Sleep is a state of behavioral change including body position, body movement, response to stimuli, alertness, eyelids and eye movements, as well as electroencephalography (EEG), electrooculography (EOG), and electromyography (EMG) [2]. Sleep behavior changes through age. Sleep changes significantly during the first few years of life, as well as during transition to adolescence which the baby's sleep period averages 17-19 hours per day gradually decreases to $8-9$ hour [3]. During puberty, the body's biological changes which called circadian rhythm occurs, thus adolescent tends to sleep at midnight and wake up earlier in the morning [4].

In the last few decades, epidemiological research has revealed that the number sleep disorders increased in adolescents [5]. Natalita et al [6] found 62.5\% junior high school students in Bekasi suffered sleep disorders. In addition a study in East Jakarta research among 92 Junior High School students in 2009 and found the prevalence of sleep disorder was $62.9 \%$ [5]. Research among junior and senior high school students in Japan showed prevalence of sleep disorders were 15.3 and $39.2 \%$, depends on gender, sleep duration and nap [7]. Bruni et al., [8] found the prevalence of sleep disorder in public school of Rome was 


\section{$73.4 \%$.}

Sleep disorders in adolescents are influenced by various factors [5] such as extracurricular activities, watching television, using computers, using cell phones and homework can delay bedtime. Sleep disorders is a serious condition that can affect learning ability, school performance and behavioral function [1]. Caffeine, nicotine and illegal drugs also affect adolescent's sleep time [9]. Several medical factors also affect sleep, including neuropsychiatric disorders and chronic illnesses, such as nocturnal asthma [10] and atopic dermatitis [5].

The gold standard for diagnosing sleep disorders is polysomnography (PSG). However this examination is very expensive, requires hospitalization and need specialists to interpret the results. An alternative tool for diagnosing sleep disorders is wrist actigraphy, but this tool is not available in Indonesia. The sleep disturbance scale for children (SDSC) is an inexpensive, easy and effective screening instrument for early detection of sleep disorders in adolescents. The sensitivity and specificity of SDSC to wrist actigraphy were $71.4 \%$ and $54.5 \%$. The SDSC instrument can be used as sleep disorder screening tool in adolescents and has been validated in Indonesian $[6,8]$.

The adolescent's age range from 10 to 18 years old [11]. Adolescents are among the high risk group for sleep disorders [12]. Short sleep duration in adolescents is associated with many factors and late sleep time is the most significant predictor [13]. Changes of biological clock (circadian rhythm) result in sleep delay with tendency to sleep later and wake up earlier in the morning frequently occurs in early to mid-adolescence period [13-15], which is period of junior high school.

SMP Santo Yoseph, one of the leading private schools in Denpasar. [14] Easy access, located in middle of the city and busy schedule of school activities are the main reasons for selecting it for this research. Based on the pattern of school hours in Indonesia, and adolescent's activity outside school hours and lifestyle, it is estimated that sleep disturbance is a common problem in Indonesia, especially in adolescents aged 12-15 years old in SMP Santo Yoseph Denpasar - Bali. This underlies the importance for exploring the prevalence of sleep disorders and risk factors for sleep disorders among adolescents in SMP Santo Yoseph Denpasar - Bali.

\section{Method}

This was a descriptive study using cross-sectional design. Data was collected using the SDSC questionnaire which has been filled in at school or at home by parents of each student and carried out in August 2019 at SMP "Santo Yoseph" Denpasar, Bali. The inclusion criteria was students who were registered at SMP Santo Yoseph in Denpasar aged 12-15 years old and live with their parents / guardians for at least 6 months. Students who did not attend school due to illness or any reason at the time of sample collection, parents who were unwilling to participate in the study, and students who had medical problems such as neuropsychiatric disorders and chronic diseases, such as asthma and atopic dermatitis were excluded from this study.

Sampling was collected by stratified purposive sampling technique. Subjects were divided into class I, II, and III. The minimum sample size we needed to find the prevalence ratio was 92 subjects.

Data analysis was performed by assessing prevalence and risk factor analysis of sleep disturbance. The prevalence assessment was presented descriptively in the form of number (n) and percentage (\%), while risk factor analysis to determine the relationship between various risk factors and sleep disorders, is divided into two steps. The first step, bivariate analysis was tested with the chi-square test and calculation of prevalence ratio (PR) and 95\% confidence interval (CI). The second step was multivariate analysis with logistic regression models. Multivariate analysis variables were variables of bivariate analysis which had $\mathrm{p}$-value $<0.25$. The results of the multivariate analysis were expressed as PR with CI $95 \%$. The significant level for all hypothesis tests was set as $p<0.05$. Data analysis was performed by computer program and presented in tabular form.

This study had been approved ethically from Ethics Committee of the Research and Development Unit (Litbang) of Udayana Medical Faculty / Sanglah Hospital No: 2595 / UN14.2.2. VII.14 / LP / 2019.

\section{Result}

Among 92 respondents who met the inclusion and exclusion criteria. The characteristics of the research subjects is listed in Table 1.

Table 1. The characteristics of the research subjects.

\begin{tabular}{|c|c|}
\hline Variable & $\mathbf{N}=\mathbf{9 2}$ \\
\hline \multicolumn{2}{|l|}{ Gender, n (\%) } \\
\hline Male & $48(52.2)$ \\
\hline Female & $44(47.8)$ \\
\hline \multicolumn{2}{|l|}{ Class, n (\%) } \\
\hline Class 1 (12-<13 years old) & $31(33.7)$ \\
\hline Class $2(13-<14$ years old $)$ & $31(33.7)$ \\
\hline Class 3 (14- 15 years old) & $30(32.6)$ \\
\hline \multicolumn{2}{|l|}{ Extracurricular activities, n (\%) } \\
\hline Yes & $65(70.7)$ \\
\hline No & $27(29.3)$ \\
\hline \multicolumn{2}{|l|}{ Nap habits, n (\%) } \\
\hline Yes & $49(53.3)$ \\
\hline No & $43(46.7)$ \\
\hline \multicolumn{2}{|l|}{ Consumption of caffeine, $\mathrm{n}(\%)$} \\
\hline Yes & $39(42.4)$ \\
\hline No & $53(57.6)$ \\
\hline \multicolumn{2}{|l|}{ Watching television, $\mathrm{n}(\%)$} \\
\hline Yes & $67(72.8)$ \\
\hline No & $25(27.2)$ \\
\hline \multicolumn{2}{|l|}{ Using computer, n (\%) } \\
\hline Yes & $45(48.9)$ \\
\hline No & $47(51.1)$ \\
\hline \multicolumn{2}{|l|}{ Playing cell phone, n (\%) } \\
\hline Yes & $65(70.7)$ \\
\hline No & $27(29.3)$ \\
\hline
\end{tabular}


Table 2. The characteristic of sleep among subjects according to the sleep disturbance scale on children.

\begin{tabular}{ll}
\hline Charaacteristic of Sleep & $\mathbf{N = 9 2}$ \\
\hline Without sleep disorders, $\mathrm{n}(\%)$ & $48(52.2)$ \\
Experiencing sleep disorders, $\mathrm{n}(\%)$ & $44(47.8)$ \\
Dissorders of initiating and maintaining sleep, $\mathrm{n}(\%)$ & $21(22.8)$ \\
Sleep breathing disorders, $\mathrm{n}(\%)$ & $6(6.5)$ \\
Dissorders of arousal, $\mathrm{n}(\%)$ & $2(2.2)$ \\
Sleep wake transition disorders, $\mathrm{n}(\%)$ & $13(14.1)$ \\
Disorders of excessive somnolence, $\mathrm{n}(\%)$ & $2(2.2)$ \\
Sleep hyperhydrosis, $\mathrm{n}(\%)$ & $0(0.0)$ \\
\hline
\end{tabular}

Based on the results of SDSC questionnaire, it was found that $47.8 \%$ of subjects experienced sleep disorders, they were subjects with SDSC score above 39. The most common types of sleep disorders was disorders of initiating and maintaining sleep $(22.8 \%)$. The distribution of subjects according to the sleep disturbance scale on children are listed in Table 2.

Based on bivariate analysis on respondents' activities with sleep disorders, it was found that watching television, using computers and playing cell phones were statistically significant (p-value $<0.05, \mathrm{RP}$ and CI 95\% values were more than 1), which means that these variables are risk factors for sleep disorders. The bivariate analysis of the respondents' activities with sleep disorders is shown in Table 3.

Table 3. The bivariate analysis of the respondents' activities with sleep disorders.

\begin{tabular}{|c|c|c|c|c|c|}
\hline \multirow{2}{*}{ Variable } & \multicolumn{2}{|c|}{ Sleep disorders } & \multirow{2}{*}{ p-value } & \multirow{2}{*}{$\mathbf{R P}$} & \multirow{2}{*}{ CI $95 \%$} \\
\hline & Yes $(\mathrm{N}=44)$ & No $(\mathrm{N}=48)$ & & & \\
\hline Extracurricular activities, $\mathrm{n}(\%)$ & & & 0.07 & 2.3 & $0.94-5.95$ \\
\hline Yes & $35(38.0)$ & $30(32.6)$ & & & \\
\hline No & $9(9.8)$ & $18(19.6)$ & & & \\
\hline Nap habits, n (\%) & & & 0.28 & 1.57 & $0.68-3.58$ \\
\hline Yes & $26(28.3)$ & $23(25.0)$ & & & \\
\hline No & $18(19.6)$ & $25(27.2)$ & & & \\
\hline Consumption of caffeine, $\mathrm{n}(\%)$ & & & 0.78 & 0.89 & $0.38-2.03$ \\
\hline Yes & $18(19.6)$ & $21(22.8)$ & & & \\
\hline No & $26(28.3)$ & $27(29.3)$ & & & \\
\hline Watching television, $\mathrm{n}(\%)$ & & & 0.02 & 3.17 & $1.17-8.59$ \\
\hline Yes & $37(40.2)$ & $30(32.6)$ & & & \\
\hline No & $7(7.6)$ & $18(19.6)$ & & & \\
\hline Using computer, $\mathrm{n}(\%)$ & & & 0.02 & 2.64 & $1.14-6.14$ \\
\hline Yes & $27(29.3)$ & $18(19.6)$ & & & \\
\hline No & $17(18.5)$ & $30(32.6)$ & & & \\
\hline Playing cell phone, n (\%) & & & 0.02 & 2.94 & $1.12-7.7$ \\
\hline Yes & $36(39.1)$ & $29(31.5)$ & & & \\
\hline No & $8(8.7)$ & 19 (20.7) & & & \\
\hline
\end{tabular}

Logistic regression analysis showed that three variables had positive relationship with sleep disorders, as indicated by positive value and statistically significant proven by $p$-value $<0.05$. The three variables have significant relationship with sleep disorders, such as watching television, using computer, and playing cell phone. Each of these factor has risk 3.5 times vs 2.8 times vs 2.9 times of suffering sleep disorders compared to not watching television, not using computer and not playing cell phone with confidence interval of $95 \%$ above 1. The results of the logistic regression analysis are shown in Table 4.

Table 4. The results of logistic regression analysis.

\begin{tabular}{llll}
\hline Variable & p-value & RP & CI 95\% \\
\hline Watching television & 0.02 & 3.51 & $1.20-10.23$ \\
Using computer & 0.04 & 2.85 & $1.02-7.90$ \\
Playing cell phone & 0.01 & 2.97 & $1.20-7.38$ \\
\hline
\end{tabular}

\section{Discussion}

Sleep disturbance screening tests in children can be done with various screening devices. One of the sleep disturbance screening tests is SDSC questionnaire $[5,6,8]$. Based on the results of the questionnaire filled by parents / guardians, most of them thought that their child do not have sleep disturbance.
Parents often ignore the symptoms of sleep disorders in children and assume that sleep disorders do not require medical intervention [12]. This is consistent with Blunden et al. [12], whom sated only $4.1 \%$ parents concerns about sleep disorders in children. This under-reporting due to parents do not understand the impact of sleep disorders on children such as decreased academic performance, impaired neurocognitive function and increased problems with daytime sleep [16].

This study showed that the prevalence of sleep disorders among adolescents aged 12-15 years old in SMP Santo Yoseph Denpasar was $47.8 \%$. This result is lower than Haryono et al., [5] whom found prevalance of sleep disorder $62.9 \%$ in SMP "Negeri 92" Jakarta and Natalita et al., [6] whom found prevalence of sleep disorder was $62.5 \%$ in SLTP "Galatia", Bekasi. Both studies also used the SDSC method. This difference can be due to differences in environmental conditions with those studies, where both studies were conducted in megapolitan city with population more than nine million people. LeBourgeois et al. [17] stated that adolescent who live in big cities often experiences sleep disorders due to more noisy sleeping environment. Our study also found that the most common types of sleep disorders was initiating and maintaining sleep (22.8\%). Our results are corroborated by Hysing et al. [18], in Norway which showed difficulty in initiating and maintaining sleep was found to be $23.8 \%$. 
Our study also found no statistical association between extracurricular activities and sleep disturbances. This result is different from Widome et al., [16] whom found an association between extracurricular activities and sleep disorders. This difference could be due to differences in the types of extracurricular activities and measurement tool which used survey of sleep habits. The extracurricular program has functions of personal development, potential, character building and skills training, social functions to develop abilities and sense of social responsibility, creative functions to support the development process and career preparation. In addition it provide relaxed and pleasant atmosphere that supports adequate sleep [16]. However, the type of extracurricular activities that affect sleep were not studied further.

Nap habit and sleep disorders didn't show significance relationship in our study. Our findings differ from Gradisar et al. [19], which showed $32 \%$ of students took naps 4 times a week on average. Gradisar stated naps can cause significant delay in subjects who do not have nap habit. This difference is due to differences in measurement tools and the average sleep per day. The habit of sleeping during the day can reduce sleep time at night, but the impact of napping will impact on sleep time at night. Research has found teens tend to take longer naps duration (more than 30 minutes). Long nap has slow waves thus reduce the homeostatic pressure of sleep, which can lead to increased alertness at night. This show that shorter sleep duration at night could increases the desire to take nap the next day. Short naps (less than 20 minutes) does not have slow waves so this negative cycle does not occur in this study [19].

There was no association between caffeine consumption and sleep disturbances in our study. This was different from the research conducted by Snel and Lorist [18] which caffeine consumption cause longer period of awake at night thus causing daytime sleepiness, inhibits work performance due to fatigue and increases boredom. This difference can be due to differences in sample size, levels of caffeine contained in food and beverages and different instruments. Caffeine works as adenosinergic receptor antagonist when used effectively and have beneficial effects on alertness to prevent decreased work performance related with sleep deprivation, but these conditions produce adverse effect at the next bedtime [18].

Cain and Gradisar reported the most common cause of disturbance in starting and maintaining sleep in adolescents is the excessive use of technology such as television, computers and cell phones $[19,20]$. This was consistent with this study which there was a significant relationship between sleep disturbances and watching television, using computers and use of cell phones before bed. Subjects who had television in their bedroom experienced sleep disorders by $40.2 \%$ and $29.3 \%$ who used computers and $39.1 \%$ who used cell phones experienced sleep disturbances. This result is not different from Shockat et al., whom reported about $60 \%$ of adolescents have television and computer in the bedroom [21].

The impact of using electronic media is a prolonged sleep onset latency and a reduction in total sleep time due to the alternation between sleep time and activity [19]. Our findings are also corroborated by the findings of Hysing et al., [18] in the city of Hordaland, Norway who examined the relationship between sleep and electronics media in adolescents. They tend to use the electronic devices at night result in increases the risk of short sleep duration, prolonged sleep onset latency, and increased sleep deprivation. This relationship is obtained in the use of computers, watching television and using cell phones one hour before bedtime. The study recommends restrictions on the use of electronic devices.

The mechanism behind the relationship between the use of electronic media devices and sleep problems is not known certainly, but several theoretical studies have suggested a possible mechanism for this relationship [21]. Use of electronic media can directly influence sleep by compensating for sleep time due to the time-consuming. Use of electronic media increased psychophysiological urges caused by the content of the uplifting material [22, 23]. And also through exposure to bright light on most electronic media devices. Bright light can affect sleep in two ways: by delaying circadian rhythms when exposure occurs at night and also by causing radiation's effect $[24,25]$, so sleep can be negatively affected by electromagnetic radiation [24]. Another mechanism is related to physical discomfort, such as muscle aches and headaches, which can be caused by by prolonged use of the media [25].

Limitations of this study are measurements based on subjectivity and the level of activity of the subject are not monitored and the measurement of sleep disturbances using data from parent reports which allows less attention to the quality of their child's sleep. The types of extracurricular activities that were followed were not studied. Caffeine content and types of ingredients containing caffeine were not measured. The length / duration of use of each electronic media was not measured, and the use of more than one type of electronic media in each individual was not measured in our study so that further significance relationships were not analyzed. Determination using the SDSC questionnaire is not a diagnostic tool for sleep disturbance but rather as a screening tool, thus we cannot speculate on the main factors causing sleep disturbances in our subjects.

\section{Conclusion}

The prevalence of sleep disorders in adolescents is quite high. The risk factors of sleep disorders are watching television, using computer and playing cell phone/gadget. Limitation of this study it used parental report as screening measurement which could be affected by subjectivity. Measurement of risk factors for sleep disorders was carried out in broad outline without exploring in detail such as the types of extracurricular activities, the level of caffeine consumed, the length of naps, the duration of electronic media usage, and the use of more than one kind of electronic media. However the researchers hope that this research can 
be used as basis for further research to measure the role of various risk factors for sleep disorders.

\section{References}

[1] Dewald JF, Meijer AM, Oort FJ, Kerkhof GA, Bogels SM. The influence of sleep quality, sleep duration and sleepiness on school performance in children and adolescent: A metaanalytic review. Sleep medicine reviews. 2010: 179-89.

[2] Chokroverty S. Overview of sleep and sleep disorders. Indian J Med 2010; 126-40.

[3] Barclay NL, Gregory AM. Sleep in Childhood and Adolescence: Age specific sleep characteristics, common sleep disturbances and associated difficulties. The Neurobiology of Childhood. London (UK): Springer. 2013; 337-65.

[4] Dawson P. Sleep and Sleep Disorders in Children and Adolescents: Information for Parents and Educators. [cited 2019 January 5] Available from:

http://www.nasponline.org/resources/health_wellness/sleepdis orders_ho.aspx.

[5] Haryono A, Rindiarti A, Arianti A, Pawitri A, Ushuluddin A, Setiawati A, dkk. [Prevalence of Sleep Disorder in Adolescent Aged $12-15$ Years Old in Junior High School]. Prevalensi gangguan tidur pada remaja usia $12-15$ tahun di sekolah lanjutan tingkat pertama. Sari Pediatri 2009; 11: 149-54.

[6] Natalita C, Sekartini R, Poesponegoro H. [Sleep Disturbance Scale for Children (SDSC) as Screening Tool for Sleep Disorder in Junior High School Students]. Skala gangguan tidur untuk anak (SDSC) sebagai instrumen skrining gangguan tidur pada anak sekolah lanjutan tingkat pertama. Sari pediatri 2011; 6: 365-72.

[7] Ohida T, Osaki Y, Doi Y, Tanihata T, Minowa M, Suzuki K, dkk. An epidemiologic study of self-reported sleep problems among Japanese adolescents. Sleep. 2004; 27: 978-85.

[8] Bruni O, Ottaviano S, Guidetti V. The sleep disturbances scale for children (SDSC) construction and validation of an instrument to evaluate sleep Disturbances in childhood and adolescence. J. Sleep Res. 1996; 5: 251-61.

[9] Kotagal S, Pianosi P. Sleep disorders in children and adolescents. BMJ. 2006; 332: 828-32.

[10] Diette GB, Marckson L, Skinner EA, Nguyen TTH, Bergstrom PA. Nocturnal asthma in children affects school attendance, school performance, and parent's work attendance. Arch Pediatr Adolesc Med. 2000; 154: 923-28.

[11] Soetjiningsih. [Growth and Development of Adolescent and Associated Problems]. Tumbuh kembang remaja dan permasalahannya. Edisi I. Jakarta: Sagung seto; 2004. Page 12.
[12] Blunden S, Lushington K, Lorenzen B, Ooi T, Fung F, Kennedy D. Are sleep problems under-recognised in general practice? Arch Dis Child 2004; 89: 708-12.

[13] Stores G. Aspects of sleep disorders in children and adolescents. Dialogues Clin Neurosci. 2009; 11: 81-90.

[14] Tagaya H, Uchiyama M, Ohida T, Kamel Y, Shibui K, Ozaki A, dkk. Sleep habits and factors associated with short sleep duration among Japanese high-school students: A community study. Sleep and Biological Rhythms. 2004; 2: 57-64.

[15] Laberge L, Petit D, Simard C, Vitaro F, Tremblay RE. Development of sleep in early adolescence. J Sleep Res 2001; 10: 59-67.

[16] Widome R, Berger AT, Lenk KM, Erickson DJ, Laska MN, Iber C, dkk. Correlates of short sleep duration among adolescent. Journal of Adolescence. 2019; 163-67.

[17] LeBourgeois MK, Giannotti F, Cortesi F, Wolfson AR, Harsh J. The relationship between reported sleep quality and sleep hygiene in Italian and American adolescents. Pediatrics 2005; 115: 257-65.

[18] Hysing M, Pallesen S, Stormark K, Lundervold A, Sivertsen B Sleep patterns and insomnia among adolescents: a populationbased study. J Sleep Res. 2013; 22: 549-56.

[19] Gradisar M, Wright H, Robinson J, Paine S, Gamble A. Adolescent napping behavior: Comparisons of school week versus weekend sleep patterns. Sleep and Biological Rhythms. 2008; 6: 183-86.

[20] Cain N, Gradisar M. Electronic media use and sleep in schoolaged children and adolescents: a review. Sleep Med. 2010; 11: 735-42.

[21] Schochat T, Flint-Bretler O, Tzizchinsky O. Sleep patterns, electronic media exposure and daytime sleep related behaviours among Israeli adolescents. Acta Paediatr 2010; 99: 1396-400.

[22] Seputra DPGS, Windiani IGAT, Adnyana IGANS. Prevalence of Sleep Disorder in Obese Children. E-Jurnal Medika 2017; 6 (4): 39-48.

[23] Hysing M, Pallesen S, Stormark KJ, Jakobsen R, Lundervold AJ Sivertsen B. Sleep and use of electronic devices in adolescence: results from a large population-based study. BMJ. 2015; 5: 1-7.

[24] Weaver E, Gradisar M, Dohnt H, Lovato N, Douglas P. The effect of presleep video game playing on adolescent sleep. J Clin Sleep Med. 2010; 6: 184-9.

[25] Thomee S, Dellve L, Harenstam A. Perceived connections between information and communication technology use and mental symptoms among young adults - a qualitative study. BMC Public Health. 2010; 10: 66. 